\title{
Isolation and characterization of Shiga toxigenic Escherichia coli of animal and bird origin by multiplex polymerase chain reaction
}

\author{
S. Neher ${ }^{1}$, A. K. Hazarika ${ }^{1}$, L. M. Barkalita ${ }^{2}$, P. Borah' ${ }^{2}$, D. P. Bora ${ }^{1}$ and R. K. Sharma ${ }^{1}$
}

1. Department of Veterinary Microbiology, College of Veterinary Science, Assam Agricultural University, Guwahati, Assam, India; 2. Department of Animal Biotechnology, College of Veterinary Science, Assam Agricultural University, Guwahati, Assam, India.

Corresponding author: S. Neher, e-mail: samsunneher87@gmail.com, AKH: hazarikaonline@gmail.com, LMB: luitbarkalita@gmail.com, PB: borahp@vetbifguwahati.ernet.in, DPB: drdpbora@gmail.com, RKS: dr.sharmark@rediffmail.com

Received: 20-08-2015, Revised: 17-12-2015, Accepted: 21-12-2015, Published online: 08-02-2016

doi: 10.14202/vetworld.2016.123-127 How to cite this article: Neher S, Hazarika AK, Barkalita LM, Borah P, Bora DP, Sharma RK (2016) Isolation and characterization of Shiga toxigenic Escherichia coli of animal and bird origin by multiplex polymerase chain reaction, Veterinary World 9(2): 123-127.

\begin{abstract}
Aim: The purpose of this study was to determine the virulence genes and serotype of Shiga toxin producing Escherichia coli (STEC) strains isolated from animals and birds.

Materials and Methods: A total of 226 different samples viz., fecal, intestinal content, rectal swab and heart blood were collected from different clinically affected/healthy animals and birds and were streaked on McConkeys' lactose agar and eosin methylene blue agar for isolation of $E$. coli, confirmed by staining characteristics and biochemical tests. By polymerase chain reaction (PCR) all the $E$. coli isolates were screened for certain virulence genes, viz., Shiga toxin 1 (stx 1 ), stx 2 and eae and enterohemolytic (Ehly) phenotype was observed in washed sheep blood agar plate. All the isolated E. coli strains were forwarded to the National Salmonella and Escherichia Centre, Central Research Institute, Kasauli (Himachal Pradesh) for serotyping.
\end{abstract}

Results: Out of 226 samples 138 yielded E. coli. All the isolates were screened for molecular detection of different virulent genes, viz. stx1, stx2 and eae, based on which $36(26.08 \%)$ were identified as STEC. Among those STEC isolates, $15(41.67 \%), 14(38.89 \%), 1(2.78 \%)$ exhibited eae, stx2, stx 1 alone, respectively, whereas $4(11.11 \%)$ and $2(5.56 \%)$ carried both stx 1 and stx2, stx 2 and eae, respectively. Among the STEC isolates 22 were belonged to 15 different sero-groups, viz., O2, O20, O22, O25, O43, O60, O69, O90, O91, O95, O106, O118, O130, O162 and O170 and others were untypable. Ehly phenotype was observed in $10(27.78 \%)$ the STEC isolates.

Conclusion: The present study concluded that STEC could be isolated from both clinically affected as well as healthy animals and birds. Regular monitoring of more samples from animal and bird origin is important to identify natural reservoir of STEC to prevent zoonotic infection.

Keywords: eae, Escherichia coli, Shiga toxigenic Escherichia coli, Shiga toxin 1, Shiga toxin 2.

\section{Introduction}

Shiga toxigenic Escherichia coli (STEC) is considered to be the most common foodborne zoonotic pathogen causing various disease conditions in both animals and humans [1]. Ruminants are the most important source of STEC with cattle being regarded as the primary reservoir [2-4]. In humans, STEC infections may primarily result from consumption of undercooked beef, raw milk, meat and dairy products, vegetables, unpasteurized fruit juices, and water contaminated with feces of animal $[5,6]$. The virulent strains of STEC are associated with one or more types of Shiga toxin (stx1, stx2 or stx2 variants) as well as the property of producing intimin, which is required for attachment effacement lesions

Copyright: Neher, et al. Open Access. This article is distributed under the terms of the Creative Commons Attribution 4.0 International License (http://creativecommons.org/licenses/by/4.0/), which permits unrestricted use, distribution, and reproduction in any medium, provided you give appropriate credit to the original author(s) and the source, provide a link to the Creative Commons license, and indicate if changes were made. The Creative Commons Public Domain Dedication waiver (http://creativecommons.org/ publicdomain/zero/1.0/) applies to the data made available in this article, unless otherwise stated. encoded by eae gene [2,7]. There are, at least, 200 serotypes of $E$. coli that are capable of producing shigatoxins [8-10]. However, of these serotypes $E$. coli $\mathrm{O} 157: \mathrm{H7}$ is the most well-known to both microbiologists and the general public, but several nonO157 STEC strains are also associated with the production of shigatoxins [1,2,8,11-14].

Isolation of $\mathrm{O} 157: \mathrm{H7}, \mathrm{O} 157: \mathrm{H}$ - or the other STEC serotypes from dairy cattle emphasize the role of raw milk as an important vehicle of transmission $[3,15]$. In animals, STEC is associated with hemorrhagic colitis (HC), hemolytic uremic syndrome (HUS), and edema disease in pig [1,16-18]. Pathogenic strains of $E$. coli that cause diseases are difficult to distinguish from those constitute a part of the normal intestinal flora of animals and man. Therefore, it is imperative to characterize the isolates in terms of their virulence factors so as to establish their pathogenic significance. Pathogenic strains of $E$. coli can be identified by detection of their toxins and toxin genes.

Considering the public health importance of STEC, it is necessary to isolate and characterize the 
STEC strains circulating in a particular region, so that appropriate control strategies could be adopted. This paper reports about characterization of STEC isolated from animals and birds of Assam, the Northeastern state of India based on molecular detection of certain virulence genes in the isolates.

\section{Materials and Methods}

\section{Ethical approval}

Ethical approval for the study was obtained from Institutional Animal ethics Committee of College of Veterinary Science, Assam Agricultural University, Khanapara.

\section{Source of sample}

A total of 226 different samples, viz., fecal, intestinal content, rectal swab, and heart blood were collected aseptically in sample collection vial from apparently healthy and clinically ill/dead animals and birds from organized and some un-organized farms in and around Guwahati city.

\section{Isolation and identification of $E$. coli}

All samples were primarily inoculated in McConkeys' lactose agar plates and, later on, lactose fermenting colonies were subcultivated on eosin methylene blue agar medium to observe characteristic metallic sheen. Further identification was done on the basis of staining procedure and different biochemical tests as described by Edwards and Ewing [19].

\section{Serotyping of $E$. coli}

The isolated $E$. coli strains were serotyped on the basis of somatic $(\mathrm{O})$ and flagellar $(\mathrm{H})$ antigens in the National Salmonella and Escherichia Centre, Central Research Institute, Kasauli (Himachal Pradesh) as per method of Edwards and Ewing [19].

\section{Molecular characterization by multiplex polymerase chain reaction (M-PCR)}

All the E. coli isolates were screened for certain virulence genes, viz., stx 1, stx 2 and eae genes by multiplex PCR [20]. The template DNA was obtained from each $E$. coli isolate by hot cold lysis procedure as per the method described by Titball et al., 1989 [21]. Briefly, 16-18 h growth of E. coli were obtained in $2 \mathrm{ml}$ Luria Bertoni broth. Broth cultures were centrifuged at $12,000 \mathrm{rpm}$ for $10 \mathrm{~min}$ at $4^{\circ} \mathrm{C}$. The pellets were resuspended in $75 \mu \mathrm{l}$ of tris ethylene-diamine-tetraacetic acid buffer and heated in boiling water bath at $100^{\circ} \mathrm{C}$ for $20 \mathrm{~min}$, followed by snap chilling in ice for $20 \mathrm{~min}$ and finally centrifuged at $12,000 \mathrm{rpm}$ for $20 \mathrm{~min}$ at $4{ }^{\circ} \mathrm{C}$. The supernatant was directly used as template DNA for PCR for screening of virulence genes. The extracted DNA was subjected to multiplex PCR for screening of stx 1, stx 2 and eae genes using specific primers (Table-1). PCR was carried out with a 25.0 $\mu 1$ final reaction volume in $\times 2$ Dream Taq Green PCR Master mix (Fermentas, USA), comprising $4 \mathrm{mM}$ $\mathrm{MgCl}_{2} 0.4 \mathrm{mM}$ of each deoxynucleotides, 0.05 units/ $\mathrm{ml}$ of Taq DNA polymerase, $150 \mathrm{mM}$ tris-HCL PCR buffer, $0.5 \mu 1$ (10 pmole/ $\mu 1)$ each of primer for $s t x 1$ and eae gene and $1.0 \mu \mathrm{l}(20 \mathrm{pmole} / \mu \mathrm{l})$ of primer for st $x 2$ gene. The thermal cyclic condition was $96^{\circ} \mathrm{C}$ for $4 \mathrm{~min}, 35$ cycles of $95^{\circ} \mathrm{C}$ for $20 \mathrm{~s}, 57^{\circ} \mathrm{C}$ for $20 \mathrm{~s}, 72^{\circ} \mathrm{C}$ for $1 \mathrm{~min}$ followed by $72^{\circ} \mathrm{C}$ for $7 \mathrm{~min}$ in a gradient thermal cycler (Techne, Germany).

The PCR amplified products were separated by electrophoresis at $85 \mathrm{~V}$ for $1 \mathrm{~h}$ with $1.8 \%(\mathrm{w} / \mathrm{v})$ agarose gel containing ethidium bromide $(0.5 \mu \mathrm{g} / \mathrm{ml})$ in $\times 1$ tris-borate-EDTA along with gene ruler $100 \mathrm{bp}$ DNA ladder (Fermentas, USA) as a molecular weight marker and visualized as a single compact band of expected size under ultraviolet light in gel documentary system (Kodak, Germany).

\section{In-vitro expression of enterohemolysin (Ehly)}

All the 36 (26.08\%) STEC strains identified by PCR was tested for production of Ehly by inoculating on washed sheep blood agar plates supplemented with $10 \mathrm{mM} \mathrm{CaCl}$ as per Beutin et al., 1989 [23]. After streaking, the plates were incubated at $37^{\circ} \mathrm{C}$ and examined at 4 and $24 \mathrm{~h}$ intervals. E. coli, which produced hemolytic reaction after $4 \mathrm{~h}$ and clear zone after $24 \mathrm{~h}$, was considered as alpha-hemolytic, whereas strains producing small turbid hemolytic zone around the streaking line after $18-20 \mathrm{~h}$ were considered as Ehly. Non-hemolytic strains gave no reaction either after $4 \mathrm{~h}$ or $24 \mathrm{~h}$.

\section{Results}

A total of 226 different samples, viz., fecal, intestinal content, rectal swab, and heart blood were collected from apparently healthy and clinically ill/dead animals and birds. All the samples were tested for isolation of E. coli. Out of all the samples 138 (61.06\%) were found to be positive for $E$. coli irrespective of the health status of the host. All the isolates were tested for the presence of certain virulence genes viz. stx 1, stx 2 and eae by Multiplex-PCR (Figure-1). Among the 138

Table-1: Details of primers used for PCR reaction.

\begin{tabular}{|c|c|c|c|c|}
\hline Primers & Sequence (5'-3') & Target gene & Amplicon (bp) & References \\
\hline $\operatorname{stx} 1(\mathrm{~F})$ & CAG TTA ATG TGG TGG CGA AGG & $\operatorname{stx} 1$ & 348 & {$[22]$} \\
\hline $\operatorname{stx} 1(\mathrm{R})$ & CAC CAG ACA ATG TAA CCG CTG & & & \\
\hline stx2 (F) & ATC CTA TTC CCG GGA GTT TAC G & $\operatorname{stx} 2$ & 584 & {$[22]$} \\
\hline stx2 (R) & GCG TCA TCG TAT ACA CAG GAG C & & & \\
\hline eae $(\mathrm{F})$ & TCA ATG CAG TTC CGT TAT CAG TT & eae & 482 & {$[20]$} \\
\hline eae $(R)$ & GTA AAG TCC GTT ACC CCA ACC TG & & & \\
\hline
\end{tabular}

$\mathrm{PCR}=$ Polymerase chain reaction, st $x=$ Shiga toxin 
isolates a total of $36(26.08 \%)$ isolates were identified as STEC. The highest isolation of STEC was exhibited by the clinically affected animals (19), followed by apparently healthy animals (12), clinically ill birds (3), and apparently healthy birds (2). Among the STEC isolates, 15 (41.67\%) exhibited eae gene alone, $14(38.89 \%)$ were positive for $s t x 2$ alone, both $s t x 1$ and stx 2 were found in $4(11.11 \%), 2(5.56 \%)$ isolates exhibited stx 2 and eae together while $1(2.78 \%)$ isolate showed stx 1 alone (Table-2). Among all the 36 STEC isolates 22 belonged to 15 different serogroups, viz., O2, O20, O22, O25, O43, O60, O69, O90, O91, O95, $\mathrm{O} 106, \mathrm{O} 118, \mathrm{O} 130, \mathrm{O} 162$ and $\mathrm{O} 170$ and others were either untypable or rough strain irrespective of type and health status of hosts. On in-vitro Ehly expression study, 17 (47.22\%) out of 36 STEC isolates exhibited the Ehly phenotype $(E-H l y)$ on washed sheep blood agar supplemented with $\mathrm{CaCl}_{2}$. All the 17 isolates they were found to be belonging to the serogroups $\mathrm{O} 2$, O22, O60, O69, O90, O91, O95 and O118with stx1, stx 2 or eae gene singly or in combination.

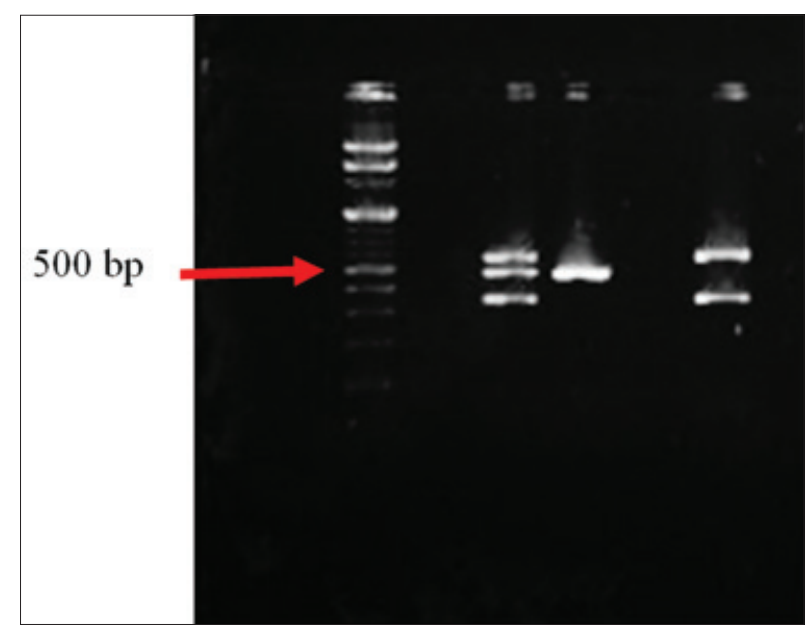

Figure-1: Gel electrophoresis picture of multiplex polymerase chain reaction of Shiga toxigenic Escherichia coli. Lane $1=100$ bp DNA ladder (Fermentus)

Lane $2=$ Negative control (NTC)

Lane $3=$ Positive control (548 bp, 482 bp, 348 bp)

Lane $4=$ Test isolate positive for eae (482 bp)

Lane $6=$ Test isolate positive for both st 1 and st $x 2$ (348 bp, $584 \mathrm{bp}$ )

\section{Discussion}

STEC an emerging human pathogen of public health concern, are able to cause serious disease in humans including mild non-bloody or severe bloody diarrhea, HC, life-threatening condition HUS and thrombocytopenic purpura; in pig it is associated with edema disease. Transmission of STEC to humans can occur as a result of direct contact with STEC-contaminated fecal material, from handling or petting animals, or by exposure to focally contaminated mud or vegetation during recreational activities. Pathogenic strains of E. coli can be identified by detection of their toxins and toxin genes. E. coli O157:H7 serotype is the most well-known STEC serotype but several other non-O157:H7 is also important in terms of virulence. A detection of different genes of STEC in adult cattle, calves, sheep, pigs and goats by PCR was also reported by previous workers [24,25]. The stx 1, st $x 2$ and eae genes encode for Stx1, Stx2 and intimin respectively, which are the characteristics cytotoxins released by STEC. In the present study, eae gene was found in the highest numbers followed by stx 2 gene. A high prevalence of eae positivity reflects the presence of locus for enterocyte attaching and effacing lesions, responsible for host colonization and virulence by STEC [26]. Strains carrying eae and stx 2 are considered to be more pathogenic to humans and especially stx 2 is being the most important virulence factor associated with the human disease like HUS and HC $[8,27]$. Ehly production is also associated with STEC infection, and those strains are called as Ehly E. coli. It has been suggested that stx, eae gene and Ehly might have synergistic action in causing disease during STEC infection [28]. The present findings showed a close association between stx and E-hlyproduction. These findings assumed a special significance in terms of potential public health hazards as these may be cross transferred to man via food chain.

\section{Conclusion}

The present study was undertaken to isolate and characterize STEC from animals and birds for zoonotic significance. The serotypes found in the present

Table-2: Isolation and molecular characterization of STEC of animal and bird origin.

\begin{tabular}{|c|c|c|c|c|c|c|c|c|c|c|}
\hline \multirow[t]{2}{*}{ Source } & \multirow{2}{*}{$\begin{array}{l}\text { Health } \\
\text { status }\end{array}$} & \multirow{2}{*}{$\begin{array}{c}\text { Number of } \\
\text { samples } \\
\text { screened }\end{array}$} & \multirow{2}{*}{$\begin{array}{c}\text { Number of } \\
\text { samples } \\
\text { positive } \\
\text { for } E \text {. coli }\end{array}$} & \multirow{2}{*}{$\begin{array}{l}\text { Number } \\
\text { of } E \text {. coli } \\
\text { isolates }\end{array}$} & \multirow{2}{*}{$\begin{array}{l}\text { Number } \\
\text { of STEC } \\
\text { isolates }\end{array}$} & \multicolumn{5}{|c|}{ Number of isolates positive for virulence gene } \\
\hline & & & & & & stx 1 & stx 2 & $\begin{array}{c}\text { stx } 1+ \\
\text { stx } 2\end{array}$ & $\begin{array}{c}\text { stx } 2+ \\
\text { eae }\end{array}$ & eae \\
\hline \multirow[t]{2}{*}{ Ani-mal } & $\begin{array}{l}\text { Clinically } \\
\text { ill/dead }\end{array}$ & 84 & $58(42.03)$ & 58 & 19 & - & 14 & 4 & 2 & 11 \\
\hline & $\begin{array}{l}\text { Apparently } \\
\text { healthy }\end{array}$ & 85 & $50(36.23)$ & 50 & 12 & & & & & \\
\hline \multirow[t]{2}{*}{ Bird } & $\begin{array}{l}\text { Clinically } \\
\text { ill/dead }\end{array}$ & 32 & $14(10.14)$ & 14 & 3 & 1 & - & - & - & 4 \\
\hline & $\begin{array}{l}\text { Apparently } \\
\text { healthy }\end{array}$ & 25 & $16(11.59)$ & 16 & 2 & & & & & \\
\hline Total & & 226 & $138(61.06)$ & 138 & $36(26.08)$ & $1(2.78)$ & $14(38.89)$ & $4(11.11)$ & $2(5.56)$ & $15(41.67)$ \\
\hline
\end{tabular}

Figures in the parenthesis indicate percentages. STEC=Shiga toxigenic Escherichia coli, stx: Shiga toxin 
study might be of zoonotic importance. STEC could be isolated from both clinically affected as well as healthy animals and birds. The highest numbers of STEC could be isolated from clinically affected animals and birds than healthy individual. Multiplex PCR used in this study provides a simple, highly sensitive, specific and rapid technique for detection of STECmediated disease. The epidemiological and zoonotic significance of STEC isolates need special emphasis for improved diagnosis, control and surveillance measures.

\section{Authors' Contributions}

$\mathrm{AKH}$ and $\mathrm{PB}$ designed the experiment. SN and LMB collected sample and performed the experiment. Manuscript preparation was supervised, reviewed and edited by RKS and DPB. All authors read and approved the final manuscript.

\section{Acknowledgments}

The authors wish to thank Head of the Department, Department of Microbiology, College of Veterinary Science, AAU, Khanapara for providing necessary facilities for the experiment.

\section{Competing Interests} interests.

The authors declare that they have no competing

\section{References}

1. Kumar, A., Taneja, N., Bharti, B. and Sharma, M. (2014) Characterization of Shiga toxigenic Escherichia coli isolated from cases of diarrhoea \& haemolytic uremic syndrome in North India. Indian J. Med. Res., 140: 778-784.

2. Perera, A., Clarke, C.M., Dykes, G.A. and Fegan, N. (2015) Characterization of Shiga toxigenic Escherichia coli $\mathrm{O} 157$ and non $\mathrm{O} 157$ isolates from ruminant feces in Malaysia. Biomed. Res. Int., 3, 1-8.

3. Sang, W.K., Boga, H.I., Waiyaki, P.G., Schnabel, D., Wamae, N.C. and Kariuki, S.M. (2012) Prevalence and genetic characteristics of Shiga toxigenic Escherichia coli from patients with diarrhoea in Maasailand, Kenya. $J$. Infect. Dev. Ctries., 6(2): 102-108.

4. Pennington, H. (2010) Escherichia coli O157. Lancet, 376: 1428-1435.

5. Beutin, L., Geier, D., Steinrück, H., Zimmermann, S. and Scheutz, F. (1993) Prevalence and some properties of verotoxin (Shiga-like toxin)-producing Escherichia coli in seven different species of healthy domestic animals. J. Clin. Microbiol., 31: 2483-2488.

6. Gill, A. and Gill, C.O. (2010) Non-O157 verotoxigenic Escherichia coli and beef: A Canadian perspective. Can. J. Vet. Res., 74: 161-169.

7. Blanco, M., Blanco, J.E., Mora, A., Dahbi, G., Alonso, M.P., Gonzalez, E.A., Bernardez, M.I. and Blanco, J. (2004) Serotypes, virulence genes and intimin types of shiga-toxin (verotoxin)-producing Escherichia coli isolates from cattle in Spain and identification of a new intimin variant gene

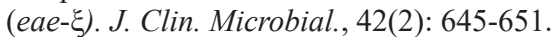

8. Kesava Naidu, G., RajendraGoud, N., Gaddad, S.M. and Shivannavar, C.T. (2011) Detection of Shigatoxin genes (stx1 \& stx2) and molecular characterization of shiga-toxigenic Escherichia coli isolated from diverse sources in Gulbarga region, India. Pharmacophore, 2(5): 253-265.

9. Rammurthy, T. (2008) Shiga toxin producing Escherichia coli (STEC): The bug in our backyard. Indian
J. Med. Res., 128: 233-236.

10. Johnson, R.P., Clarke, R.C., Wilson, J.B., Read, S.C., Rahn, K., Renwick, S.A., Sandhu, K.A., Alves, D., Karmali, M.A., Lior, H., McEwen, S.A., Spika, J.S. and Gyles., C.L. (1996) Growing concerns and recent outbreaks involving non- O157:H7 serotypes of verotoxigenic Escherichia coli. J. Food Prot., 59: 1112-1122.

11. Fey, P.D., Wickert, R.S., Rupp, M.E., Safranek, T.J. and Hinrichs, S.H. (2000) Prevalence ofnon-O157:H7 Shiga toxin-producing Escherichia coli in diarrheal stool samples from Nebraska. Emerg. Infect. Dis., 6(5): 530-533.

12. Mathusa, E.C., Chen, Y., Enache, E. and Hontz, L. (2010) Non-O157 Shiga toxin-producing Escherichia coli in foods. J. Food Prot., 73: 1721-1736.

13. Lindqvist, R. and Lindblad, M. (2011) Time to growth and inactivation of three STEC outbreak strains under conditions relevant for fermented sausages. Int. J. Food Microbiol., 145: 49-56.

14. Couturier, M.R., Lee, B., Zelyas, N. and Chui, L. (2011) Shiga-toxigenic Escherichia coli detection instool samples screened for viral gastroenteritis in Alberta, Canada. J. Clin. Microbiol., 49: 574-578

15. Perelle, S., Dilasser, F., Grout, J. and Fach, P. (2007) Screening food raw materials for the presence of the world's most frequent clinical cases of Shiga toxin-encoding Escherichia coli O26, O103, O111, O145and O157. Int. J. Food Microbiol., 113: 284-288.

16. Mora, A., López, C., Dhabi, G., López-Beceiro, A.M., Fidalgo, L.E., Díaz, E.A., Martínez-Carrasco, C., Mamani, R., Herrera, A., Blanco, J.E., Blanco, M. and Jorge Blanco, J. (2012) seropathotypes, phylogroups, stx subtypes, and intimin types of wildlife-carried, Shiga toxin-producing Escherichia coli strains with the same characteristics as human-pathogenic isolates. Appl. Environ. Microbiol., 78: 2578-2585.

17. Tarr, P.I., Gordon, C.A. and Chandler, W.L. (2005) Shigatoxin producing Escherichia coli and haemolytic uremic syndrome. Lancet, 365(9464): 1073-1086.

18. Frydendahl, K. (2002) Prevalence of serogroups and virulence genes in Escherichia coli associated with post-weaning diarrhoea and edema disease in pigs and a comparison of diagnostic approaches. Vet. Microbiol., 85(2): 169-182.

19. Edwards, P.R. and Ewing, W.H. (1986) Identification of Enterobacteriaceae. $4^{\text {th }}$ ed. Burgess Publishing Company, Minneapolis, Minnesota.

20. Vidal, M., Kruger, E., Duran, C., Lagos, R., Levine, M., Prado, V., Toro, C. and Vidal, R. (2005) Single multiplex PCR assay to identify simultaneously the six categories of diarrhoeagenic Escherichia coli associated with enteric infections. J. Clin. Microbiol., 43(10): 5362-5365.

21. Titball, R.W., Hunter, S.E., Martin, K.L., Morris, B.C., Shuttleworth, A.D., Rubidge, T., Anberson, D.W. and Kelly, D.C. (1989) Molecular cloning and nucleotide sequence of the alpha-toxin(phospholipase C) of Clostridium perfringens. Infect. Immunol., 57(2): 367-376.

22. Cebula, T.A., Payne, W.L. and Feng, P. (1995) Simultaneous identification of strains of Escherichia coli serotype O157:H7 and their Shiga-like toxin type by mismatch amplification mutation assay-multiplex PCR. J. Clin. Microbiol., 33(1): 248-250.

23. Beutin, L., Montenegro, M.A., Orskov, I., Orskov, F., Prada, J., Zimmermann, S. and Stephan, R. (1989) Close association of verotoxin (Shiga-like toxin) production with enterohemolysin production instrains of E. coli. J. Clin. Microbiol., 27: 2559-2564.

24. Rogerie, F., Marecat, A., Gambade, S., Dupond, F., Beaubois, P. and Lange, M. (2001) Characterization of Shiga toxin producing E. coli and O157 serotype E. coli isolated in France from healthy domestic cattle. Int. J. Food Microbiol., 63: 217-223.

25. Wang, G., Clark, C.G. and Rodgers, F.G. (2002) Detection in Escherichia coli of the genes encoding the major virulence 
factors, the genes defining the O157:H7 serotype, and components of the Type 2 Shiga toxin family by multiplex PCR. J. Clin. Microbiol., 40(10): 3613-3619.

26. Marches, O., Nougayrede, J.P., Boullier, S., Mainil, J., Charlier, G., Raymond, I., Pohl, P., Boury, M., Rycke, J.D., Milon, A. and Oswald, E. (2000) Role of tir and intimin in the virulence of rabbit enteropathogenic Escherichia coli serotype O103:H2. Infect. Immunol., 68: 2171-2182.
27. Ostroff, S.M., Tarr, P.I., Neill, M.A., Lewis, J.H., HargrettBean, N. and Kobayashi, J.M. (1989) Toxin genotypes and plasmid profiles as determinants of systemic sequelae in Escherichia coli O157:H7 infections. J. Infect. Dis., 160: 994-998.

28. Meng, J., Zhao, S. and Doyle, M.P. (1998) Virulence genes of Shiga-toxin producing Escherichia coli isolated from food, animals and human. Int. J. Food Microbiol., 45: 229-235.

$* * * * * * * *$ 